properties of industrial coals and in serving as a basis for allocating these coals to their most appropriate industrial purposes. In general research work also Sinnatt's fertile imagination and infectious enthusiasms were an inspiration and example to his staff.

Sinnatt's interests, however, were not limited to his own organization, since he played an active part in the work of other scientific bodies. He served on the councils of the Institution of Mining Engineers, the Institute of Fuel, the British Colliery Owners' Research Association and the British Coal Utilisation Research Association, and he was a member of the British National Committee and Executive Committee of the World Power Conference. In addition, he was a member of the Iron and Steel Industrial Research Council and chairman of the Blast Furnace Scientific Panel. He was also an original member of the Coal Research Club, an informal group of coal technologists formed just after the War of 1914-18 to further coal research and with the special object of prediscussion of papers intended for publication. In forming this Club he was associated with other personalities well known in fuel technology such as Lessing, Stopes, Wheeler and Seyler. In all these wide activities Sinnatt's opinions and views were greatly appreciated.

Although in later years Sinnatt used up all his energies in the pursuit of science, he had had diverse interests in early life, of which the most important was military training. He joined the Territorial Army in 1908, went to France as a member of the Special Brigade, R.E., in 1915, and later, when forced on medical grounds to return to Great Britain, he assumed command of the University of Manchester O.T.C.

His enthusiasm and kindly personality will be sadly missed by the many people with whom he came into contact, and particularly by the staff of the Fuel Research Organization.

J. G. KING.

\section{Prof. Rudolph Abel}

News has reached Great Britain of the death on his seventy-fourth birthday of Rudolph Abel, professor of hygiene at the University of Jena. Born on December 21, 1868, in Frankfort-on-Oder, Rudolph Abel worked as assistant in Loeffler's laboratory at Greifswald, becoming Privat-Dozent in 1893, and afterwards in 1896 assistant at the Institute of Hygiene in Hamburg.

Abel devoted himself particularly to problems more directly concerned with hygiene, publishing many papers dealing with public health and the measures to be taken in combating such diseases as diphtheria and smallpox. He was drawn into the discussion that took place after the War of $1914-18$ upon the effect which mass anti-typhoid inoculation of the male population had upon the relative incidence and mortality of typhoid in males and females in subsequent years. The rates for males were found to be very definitely lowered in comparison with those for females, and in this way a reliable indication of the lasting prophylactic effect of the war-time inoculation was obtained. He was consulted as an authority in the judicial trial which followed upon the tragic infections that occurred in Lübeck after the use of Calmette's B.C.G. vaccine.

As a Privat-Dozent at Greifswald under Loeffler, a chief whose name, with that of Klebs, will always be associated with the discovery of the diphtheria bacillus, Abel very naturally took a prominent part in the investigations of a number of problems concerned with the natural history and epidemiology of this important organism. The ground for further progress had been recently greatly cleared by Behring's discovery in 1890 of diphtheria antitoxin. Perhaps the most important discovery by Abel in this field was the demonstration in 1894 of the presence of diphtheria antitoxin in the blood of normal persons. This observation underlies much of the present-day practice of immunization against diphtheria. In the blood of diphtheria convalescents $\mathrm{Abel}$ found no antitoxin at the time of disappearance of the membrane, but some ten days later antitoxin appeared, only to vanish in the course of succeeding months. $\mathrm{He}$ made the suggestion, abundantly verified in recent years, that it is not the mere presence, but rather the amount, of diphtheria antitoxin in the blood that determines immunity.

To the carrier problem in diphtheria Abel made important contributions and also to the importance of fomites as potential sources of infection; in 1893 he had isolated virulent diphtheria bacilli from a box. of bricks $6 \frac{1}{2}$ months after a child suffering from diphtheria had played with them. Another problem that greatly interested Abel while in his twenties at Greifswald, and to which he devoted a series of bacteriological contributions, was the etiology of certain nasal conditions, in particular ozæna or atrophic rhinitis associated with the presence of organisms of the mucoid-encapsulated group, of which the prototype is Friedländer's bacillus. In his article on these organisms contributed to "Kolle and Wassermann", and to the third edition of this work edited by Kolle, Kraus and Uhlenhuth, he strongly maintained the view that from the very start of the condition of atrophic rhinitis with its accompanying ozæna, an organism found by him and known as the Bacillus mucosus ozcence played a causative part. Writing in 1938, he had to admit that his view of the etiological role of 'Kapselbacillen' in the causation of the ozæna process had not gained the acceptance of rhinologists, and indeed the precise part played by this interesting group of organisms in disease has scarcely yet been adequately elucidated.

To the great compendium of current bacteriological knowledge already alluded to, Abel provided the first chapter, dealing with the historical development of our knowledge of infective immunity throughout the centuries to the time of Pasteur. It is a concise account and should be read in conjunction with the detailed and fully documented study of this theme by Bulloch in his "History of Bacteriology", pub. lished in 1938.

After some ten or twelve years of research on pressing bacteriological problems, Abel became more interested in those of general hygiene in its relationship to the State, and he wrote widely on a variety of public health questions. In so doing he departed to some extent from the Koch tradition, which made it almost imperative that holders of chairs of hygiene in German universities should be predominantly exponents and practising professors of bacteriology. For this reason and in view of the fact that his work on bacteriology occupied only his earlier years, Abel's achievements are probably less known to present-day bacteriologists than those of many of his contemporaries who have occupied chairs of hygiene in Germany since the beginning of the present century. He will, however, be chiefly remembered in Great 
Britain as the author of a very popular "Laboratory Handbook of Bacteriology", translated and published in 1907. In Germany, other text-books from the same pen served as practical guides to bacteriology and hygiene and ran into numerous, editions.

Abel received the honorary title of Geheimer Medizinalrat in 1906 and was appointed to the chair of hygiene at Jena in 1915.

\section{Lord Hirst}

LorD HIRsT's death on January 23 at the age of seventy-nine has caused poignant regret in many circles, for he was one who touched British social life at many different points. But his outstanding contribution to national life is in the industrial field. That he founded, and built up, the General Electric Company is well known. That he set a new standard in staff relationships in industry, which gave that Company a unique character, is less well known, and is a tribute to the unerring instinct he had for singling out the essentials in all matters which he handled. In this he showed a true scientific spirit by realizing that industry is run by human beings, and broadly its organizations must be made to suit human instincts and aspirations, and not the other way round.

As soon as Lord Hirst felt his Company was large enough to support a big research laboratory, he was able to fulfil a long-standing aspiration and established the Research Laboratories of the General Electric Company at Wembley. His instinct for essentials is again to be noted. His chief objective in founding these laboratories was not the expectation of startling the world with new inventions, welcome as such have been to him when they came. His first object was to provide a scientific general staff for his Company, complete with the facilities which a large laboratory could give them.

The services of this scientific staff were not to be forced on the factory managements. They were to operate at the intermediate levels of the Company, by working on factory problems with the engineering and process staffs in the works. Most of those who are experienced in industry will concur with Lord Hirst in emphasizing this essential place in manufacturing industry, where science should have its beginning and its primary focus.

As soon as it was clear, in 1939 , that war was coming, Lord Hirst gave instructions that the research laboratories of his Company, with all their staff and facilities, should be put at the disposal of the Government without regard to commercial considerations. This offer was accepted in the letter and the spirit. The scientific assistance which his laboratories were thus enabled to bring to the war effort was a chief source of satisfaction to Lord Hirst in the closing years of a great life.

C. C. Paterson.

\section{NEWS and VIEWS}

\section{The Physical Society : Charles Chree and Duddell Medallists}

The Council of the Physical Society has awarded the Charles Chree Medal and Prize for 1943 to Prof. (now Colonel) B. F. J. Schonland and the Duddell Medal for 1942 to Dr. C. R. Burch. Col. Schonland, formerly professor of physics at Cape Town and afterwards director of the Bermard Price Institute of Geophysics at Johannesburg, is now in Great Britain doing scientific work in connexion with the War. Dr. Burch, formerly of the Research Department of the Metropolitan-Vickers Electrical Company, has continued his work in the Physics Laboratories of the Imperial College and the University of Bristol.

Prof. Schonland's work on atmospheric electricity has been primarily concerned with thunderstorm phenomena : first his investigations of the 'polarity' of thunderclouds in South Africa, and his measurement of the discharge from a small tree, which clearly established the importance of point discharges in maintaining the earth's negative charge ; secondly, his systematic long-period observations on the interrelation of thunderstorms and penetrating radiation in the southern hemisphere; and thirdly, his use of a rotating-lens camera of the Boys type in a spectacularly successful series of systematic experiments which elucidated the rather complicated succession of discharges forming what is known as a 'stroke' of lightning.

As may be seen in some of the work of the two previous Duddell medallists-Lawrence's cyclotron and Coolidge's multi-sectional high-voltage X-ray tubes-one of the outstanding characteristics of modern physics is the large-scale application of vacuum technique. It is, primarily, in recognition of Dr. Burch's valuable contributions to the advancement of such technique that the present award of the Medal is made. His invention of the oil-diffusion pump, his still for the production of vacuum oils, greases and waxes, and his development of demountable vacuum-tight joints have made possible the attainment of high vacua on an engineering scale and thus greatly increased the range of experimental investigation. It was Burch's work on the production of flat surfaces for vacuum work that aroused his own interest in the grinding of optical surfaces and the possibilities of new developments in optical technique, on which he is now engaged. His remarkable versatility is seen also in his pioneer work in the invention (with Davis) of the induction furnace. In Dr. Burch we see a very rare combination : considerable mathematical ability, exceptional experimental skill, and ability not only to design his instruments but also to construct them in the workshop; in him Duddell would have recognized a kindred spirit.

\section{The Nuffield Foundation}

LORD NUFFIELD, to whom the world is already indebted for numerous benefactions, large and small, for the benefit of research particularly in social studies, has handed over his holdings in the Nuffield organization to the value of $£ 10,000,000$ as a capital fund which will be known as the Nuffield Trust. The fund will be administered by trustees, not exceeding seven in number, and the income will be devoted to (1) medical research and teaching; (2) organization and development of medical and health services; 